\title{
Enhanced Temperature During Grain Filling Reduces Protein Concentration of Durum Wheat
}

\author{
Francesco Primo Vaccari $^{1 *}$, Roberto Ranieri ${ }^{2}$, Alessandro Matese ${ }^{1}$, Franco Miglietta ${ }^{1}$ \\ ${ }^{1}$ IBIMET - CNR, Istituto di Biometeorologia del Consiglio Nazionale delle Ricerche \\ Via Giovanni Caproni 8, 50144 Firenze, Italy \\ ${ }^{2}$ Barilla Alimentare spa \\ Via Mantova 166, 43100 Parma, Italy
}

Received: 1 October 2007. Accepted: 15 Otcober 2007.

\begin{abstract}
Durum wheat is cultivated over more than 13 millions of hectares (ha) world wide and Italy is the main European producer with 3.5 millions tons per year. The protein concentration of durum wheat is very important, it ensures high nutritional value and is highly appreciated by the pasta production industries. The protein concentration of wheat is determined during the grain filling period when carbon and nitrogen compounds are translocated into the grains. Air temperature affects translocation rates and contributes to final protein concentration of wheat grains. Two common commercial varieties of durum and bread wheat were exposed from anthesis to harvest, to a source of infrared radiation in the field. This allowed to investigate the relative effect of temperature on translocation of carbon and nitrogen compound during grain filling. The heat treatment imposed affected marginally dry mass accumulation of the grains in bread wheat and didn't affect dry mass in durum wheat. Grain protein was affected by heat treatment in durum but not in bread wheat. Carbon accumulation rate was higher for durum than for bread wheat. The protein concentration was greater in durum than in bread wheat and we can assume that the absolute nitrogen accumulation rates were higher for the former species. Such difference may be either caused by a faster nitrogen uptake rate and translocation or a more efficient relocation of nitrogen accumulated in reserve organs.
\end{abstract}

Key-words: durum wheat protein, grain filling phase, infra-red gas heaters.

\section{Introduction}

Durum wheat is mainly used for pasta production world-wide (Flagella, 2006). At present this species is cultivated over more than 13 millions of hectares (ha) (Usda, 2005) and more than 26 millions tons of grains are produced globally (Usda, 2005). In Europe durum wheat is mainly cultivated in the Southern part, Mediterranean basin, with Italy as main producer with 3.5 millions tons per year (Usda, 2005). The protein concentration of durum wheat grains is very important as it ensures high nutritional value (Gunthardt and Mc Ginnis, 1957) and is highly appreciated by the pasta production industries (Troccoli et al., 2000). The protein concentration of wheat grains is determined during the grain filling period when both carbon and nitrogen compounds are translocated; about two thirds of the protein that is stored in the wheat grain at maturity, is already present in the plant at anthesis, (Austin et al., 1977; Triboi and TriboiBlondel, 2002) while the remaining amount is absorbed from the soil during the period of the grain development (Kramer, 1979). The rate and the duration of the accumulation of proteins and carbohydrates in the grains are independent events, mainly based on source-sink relationship (Jenner et al., 1991). Water availability is known to have an influence on translocation (Campbell et al., 1981; Barber, 1987; Angus and Fischer, 1991; Rao et al., 1993; van Herwaarden et

\footnotetext{
* Corresponding Author: Tel.: +39 055 3033711; Fax: +39 055 308910. E-mail address: f.vaccari@ibimet.cnr.it
} 
al., 1998; Uhlen et al., 1998; Rharrabti et al., 2001, 2003a, 2003b) as well as nitrogen supply, through fertilization (Spiertz and van de Haar, 1978; Fischer et al., 1993; Rao et al., 1993; Anderson et al., 1995; Palta and Fillery, 1995). Usually, highest grain protein concentrations are found in wheat grown under adverse environmental conditions (Campbell et al., 1981) as the translocation of carbohydrates is more sensitive to adverse conditions than nitrogen compounds (Fernandez-Figares et al., 2000).

The effect of temperature on $\mathrm{C} / \mathrm{N}$ of wheat grains is complex as the final protein concentration depends on the relative rate of nitrogen and carbon compounds translocation but also on the duration of the grain filling period. Temperature affects both translocation rates and duration. This explain why contrasting results have been often reported in literature: temperatures higher than optimum have been observed to accelerate the rate of maturation with reductions in yield and increase in protein concentration (Dupont et al., 2006; Wrigley et al., 2006), protein concentration was observed to be reduced by heat associated to stress effect (Blumenthal et al., 1993; Corbellini et al., 1997), but other experiment was less conclusive (Spiertz et al., 2006). Genetic differences among wheat species and cultivars are considered intrinsic factors capable of affecting grain protein concentration (Bhatia, 1975; Kramer, 1979; Johnson et al., 1985; Rostami and O'Brien, 1996; Jamieson et al., 2004) especially the nitrogen transfer efficiency during post-anthesis (Jenner et al., 1991; Barbottin et al., 2005). Durum wheat is known to have nitrogen translocation rates higher than bread wheat (Ehdaie and Waines, 2001) leading to a generally higher protein concentration, but the differential effect of temperature on nitrogen relocation between those two species has never been specifically investigated.
This paper illustrates the results of an experiment in which two common commercial varieties of durum and bread wheat were exposed from anthesis to harvest, to a source of infrared radiation, in the field. This allowed to investigate the relative effect of temperature on translocation of carbon and nitrogen compound during grain filling.

\section{Materials and methods}

The experiment was done from January to July 1998 at Rapolano Terme Siena, Italy (Lat. $43^{\circ}$ $17^{\prime} \mathrm{N}$, Long. $11^{\circ} 36^{\prime} \mathrm{E}$ ) in a field of 0.5 ha with a sandy-loam soil (Tab. 1) according to the USDA soil classification. The field was ploughed in December 1997 and the latest sowing date, $17^{\text {th }}$ January 1998, was due to the rainy weather during Autumn. A strip-plot design was adopted, with two replicates, a Triticum durum (cv. Iride) and a Triticum aestivum (cv. Centauro) were sowing in row with a sowing rate of 400 germinable seeds per $\mathrm{m}^{2}$. Those two varieties were selected as having comparable earliness (Ferraresi, 2000). The field was fertilized in pre-sowing, using a Nitrogen-Phosphate fertilizer (diammonium phosphate fertilizer, 18-46) and an automatic weather station (Minimeteo-1, FMA, $\mathrm{Fi}$, Italy) was installed to the proximity of the field. After seedlings and during the growing season a Nitrogen fertilizer (Ammonium nitrate) was used to reach a total amount of 259 $\mathrm{kg} \mathrm{Nha}^{-1}$ (Tab. 2) to prevent nitrogen limitation effects. At the beginning of May 4 plots, of $250 \mathrm{~m}^{2}$ each were delimited and 4 gas-heater (Fiesta Patio Heater, Clifton Engineering Worcester Ltd - Uk) (Fig. 1a and 1b) were placed in the middle of each plots. All the gasheaters were connected to a gas tank of 5000 liters of liquid propane gas. On $19^{\text {th }}$ of May, af-

Table 1. Physical and chemical composition of soil.

\begin{tabular}{lccccc}
\hline & \multicolumn{2}{c}{ Soil texture $(\%)$} & \multicolumn{3}{c}{ Chemical composition } \\
\hline Mean & se & \multicolumn{2}{c}{ Unit } \\
Clay & 12.85 & 0.79 & $\mathrm{P}_{2} 0_{5}$ & $\mathrm{ppm}$ & 440 \\
Silt & 17.10 & 0.55 & $\mathrm{ppm}$ & 32 \\
Fine sand & 41.54 & 0.81 & $\mathrm{Kpm}$ & 120 \\
Coarse sand & 28.51 & 1.07 & pH & & 8 \\
Gravel & 8.1 & - & Organic matter & $\%$ & 0.91 \\
& & & Conductivity & $\left(\mathrm{mS} \mathrm{cm}^{-1}\right)$ & 0.0054 \\
\hline
\end{tabular}


Table 2. Dates of fertilization, type and amount of fertilizer.

\begin{tabular}{lccc}
\hline & Date & Type & Amount $\left(\mathrm{kg} \mathrm{ha}^{-1}\right)$ \\
\hline before & $17^{\text {th }}$ January & $\mathrm{N}$ & 9 \\
seeding & $\mathrm{P}$ & 10.04 & \\
\hline after & $10^{\text {th }}$ March & $\mathrm{N}$ & 50 \\
seeding & $8^{\text {th }}$ April & $\mathrm{N}$ & 50 \\
& $15^{\text {th }}$ April & $\mathrm{N}$ & 50 \\
& $6^{\text {th }}$ May & $\mathrm{N}$ & 100 \\
\hline
\end{tabular}

ter three day from the anthesis $\left(16^{\text {th }}\right.$ of May, Julian day $136=136 \mathrm{JJ})$, the heat treatment was started, the gas-heaters were kept on light only during the night. A 15 micro-termistors (Ntc, negative temperature coefficient - termistors of $10 \mathrm{kOhm}$ ) of $1.5 \mathrm{~mm}$ of diameter, were inserted directly in the ear, at different distances from the gas-heater, to monitor the temperature and connected to a data-logger (Delta-T Devices, UK), all the data were daily collected, with a time span of a minute. The main features of those temperature sensors is the low thermal inertial and then the fast response at temperature variation. The micro-termistors were placed random and at the same height of each ear, South facing the gas-heater. The gas-heaters were set at $1.80 \mathrm{~m}$ height and 3 zones exposed at different temperatures were delimited, in each plots in order to reach a temperature gradient of 5 ${ }^{\circ} \mathrm{C}$, from the heat-source to the ambient air temperature. The micro-termistors were cross-calibrated each other and were applied alternatively every week, in each plots until the harvest date ( $8^{\text {th }}$ July) when grain reach commercial humidity (less than $15 \%$ on average) on both species. Ten biomass samples were done after anthesis to the harvest, all the samples

Table 3. Sample dates and wheat growth stage (Zadoks scale).

\begin{tabular}{rccc}
\hline $\mathbf{N}^{\circ}$ & Date & Julian day & $\begin{array}{c}\text { Growth stage } \\
\text { (Zadoks scale) }\end{array}$ \\
\hline 1 & $23^{\text {th }}$ May & 143 & 70 \\
2 & $26^{\text {th }}$ May & 146 & 71 \\
3 & $28^{\text {th }}$ May & 148 & 71 \\
4 & $30^{\text {th }}$ May & 150 & 73 \\
5 & $03^{\text {rd }}$ June & 154 & 75 \\
6 & $11^{\text {th }}$ June & 162 & 77 \\
7 & $17^{\text {th }}$ June & 168 & 83 \\
8 & $25^{\text {th }}$ June & 176 & 85 \\
9 & $02^{\text {th }}$ July & 183 & 87 \\
10 & $08^{\text {th }}$ July & 189 & 91 \\
\hline
\end{tabular}
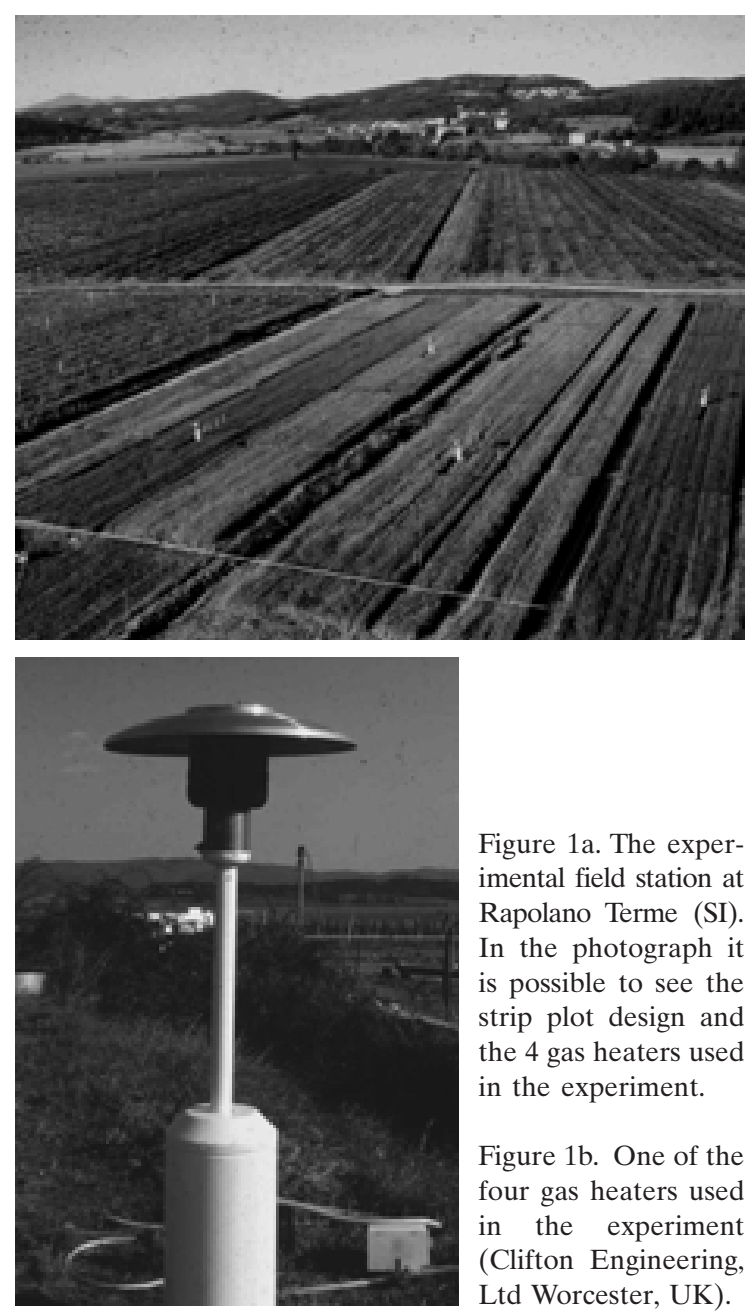

Figure 1a. The experimental field station at Rapolano Terme (SI). In the photograph it is possible to see the strip plot design and the 4 gas heaters used in the experiment.

Figure 1b. One of the four gas heaters used in the experiment (Clifton Engineering, Ltd Worcester, UK).

were collected on South facing of the plot to prevent the shade-effect of the gas-heaters (Tab. 3). At each sample date were collected 30 ears in each temperature zones for each plot, sampling operation was made by hand. Dry grains biomass per ear and protein concentration of the samples were determined. From anthesis to dough development threshing operations was made by hand, to determine dry grains biomass per ear, from dough development to ripening it has been used a portable thresher (F.lli Soprani, Li, I). Grain protein concentration was determined by a NIR Analyzer (mod. TR-3700, Foss Tecator, Denmark, DK) and the nitrogen concentration of the grain was obtained using a series of calibrations made with reference grains on which nitrogen concentraion was previously measured by Kjeldahl. The protein concentration was finally obtained multiplying the grain 
nitrogen content by the factor of 5.72 (Sosulski and Imafidon, 1990).

\section{Results}

Artificial warming was successfully achieved using the infra-red gas heaters. As expected, the infra-red gas heaters created a temperature gradient over the crop. Based on the recorded temperature of the ears, the spatial distribution of warming was reconstructed by Kriging method as illustrated in Figure 2. Three different areas having semi-circular shape could be identified as "zone A" in which the plants were subjected to an average warming of $3.6^{\circ} \mathrm{C}$ above the air temperature, "zone B" with $2.1^{\circ} \mathrm{C}$ above ambient and "zone $\mathrm{C}$ " that was at $0.5^{\circ} \mathrm{C}$ above ambient. The "zone C" was used as control since periodic measurements of average ear temperatures made at distance from the infra-red gas heater showed that $0.5{ }^{\circ} \mathrm{C}$ above ambient was a representative figure of the rest of the field. Warming made by the infra-red heater was consistent over the study period as the temperature difference between the 3 zones was maintained constant for the 45 days of the experiment (Fig. 3).

Ear emergence and subsequent plant senescence of the two species was almost synchro-

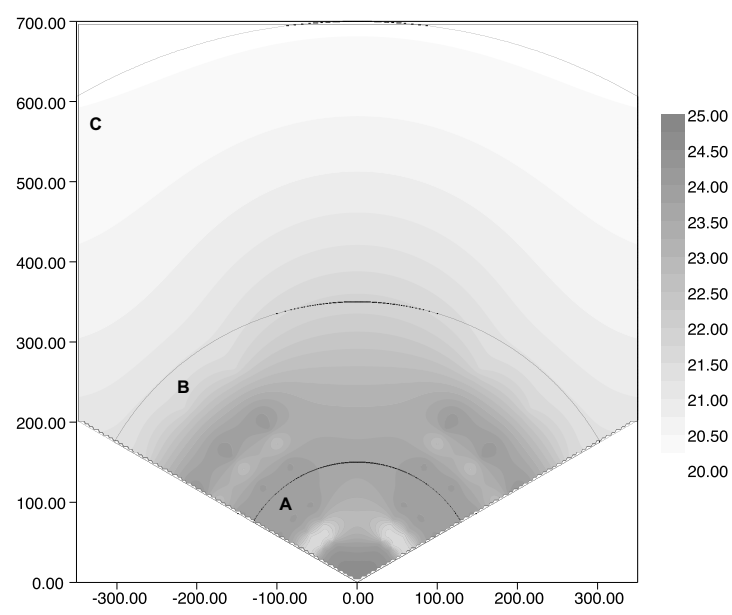

Figure 2. The graph represent the gradient temperature distribution, measured by the micro termistors directly inserted in the ears and the 3 zones delimited for each experimental plots. On $\mathrm{X}$ and $\mathrm{Y}$ axis there are the distances $(\mathrm{cm})$ from the heat-source placed on coordinates at $0 ; 0$. Values are daily average of the temperature recorded every $10 \mathrm{~min}$ utes for all the 46 days of the experiment. The grey scale represents the temperature $\left({ }^{\circ} \mathrm{C}\right)$.

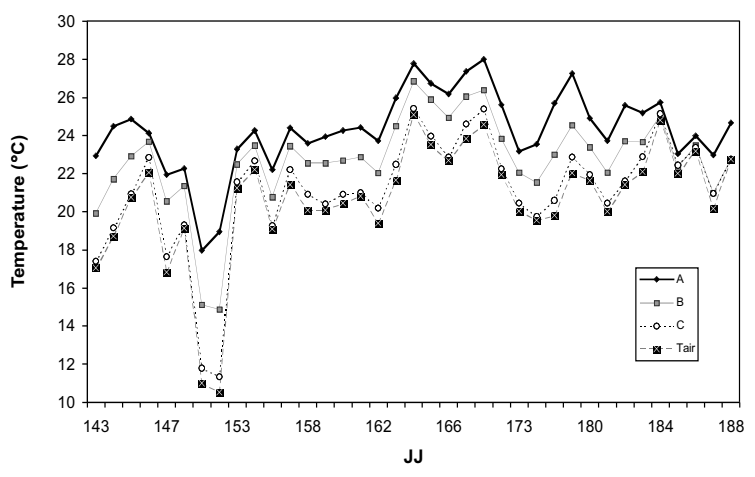

Figure 3. Daily average temperatures (23 May - 07 July) of the three zones for each plots measured by the micro termistors directly inserted in the ears, compared to the air temperature measured by the meteorological station. Zone $\mathrm{A}$ is the nearest of the gas heaters, zone B is at intermediate distance from gas heaters, and zone $\mathrm{C}$ is the zone where there isn't any effect of the gas heater.

nized ( $<2$ days difference) and their phenological development was not affected by the heat treatments. Grain filling period started on $21^{\text {st }}$ May and finished on $8^{\text {th }}$ July. No major biotic and a biotic stresses were observed before and during the experimental period.

The heat treatment only marginally affected dry mass accumulation of the grains in bread wheat (Fig. 4). The initial slope of the growing curve (from $146 \mathrm{JJ}$ to $162 \mathrm{JJ}$ ) was significant higher, at the T-test $(p<0.05)$, in the plants grown in the "zone A", compare to plants grown in the zone " $\mathrm{B}$ " and " $\mathrm{C}$ " respectively, but the difference between the dry mass of individual

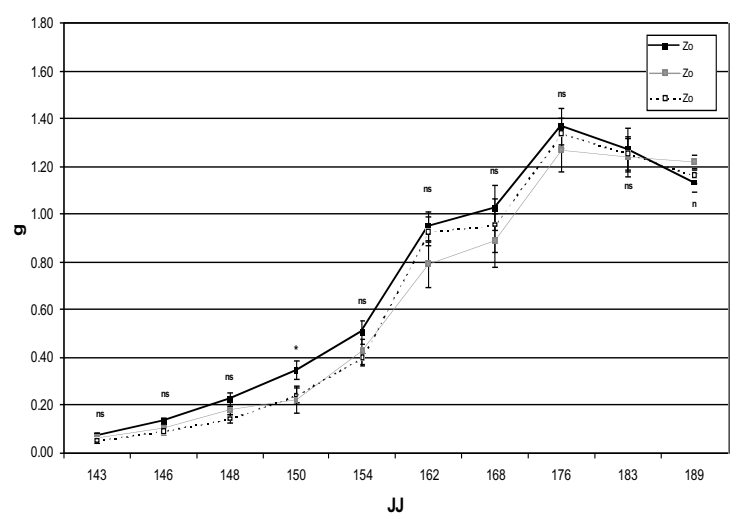

Figure 4. Dry biomass (g) per ear of Tricum aestivum (cv. Centauro). Solid symbols represent the data collected in the zone A, grey symbols data from the zone B and dotted symbols data from zone C. Statistical significant differences are shown on the graph. 


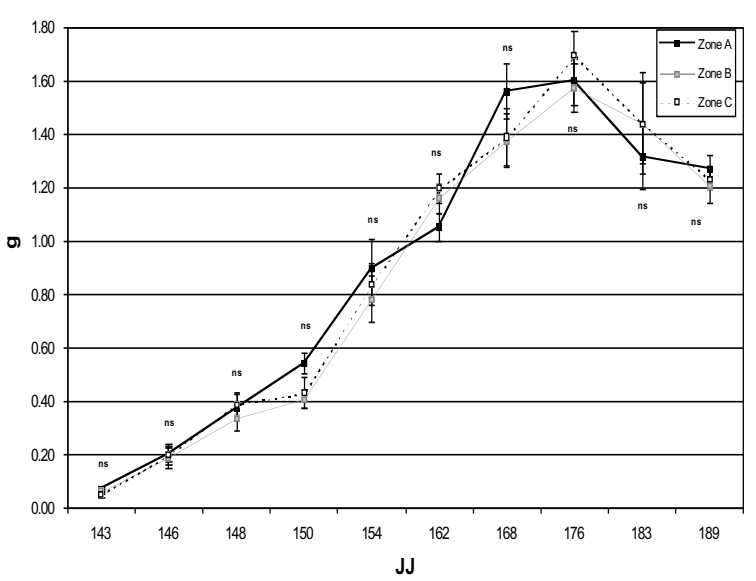

Figure 5. Dry biomass (g) per ear of Tricum durum (cv. Iride). Solid symbols represent the data collected in the zone A, grey symbols data from the zone B and dotted symbols data from zone C. Statistical significant differences are shown on the graph.

samples made at different dates throughout the experiment was only significant $(\mathrm{p}<0.05)$ on May $30^{\text {th }}$ for "zone A" compared to the remaining two (Fig. 4). Grain dry matter was not affected by warming in durum wheat (Fig. 5).

Protein concentration of the grains decreased during the initial phase of grain growth in both species and both treatments, but then increased over the last 27 days. Overall, grain protein was affected by heat treatment in durum but not in bread wheat. At none of the 10 sampling dates the protein concentration of the grains grown in zones $\mathrm{A}, \mathrm{B}$ and $\mathrm{C}$, was significantly different for bread wheat (Fig. 6). This

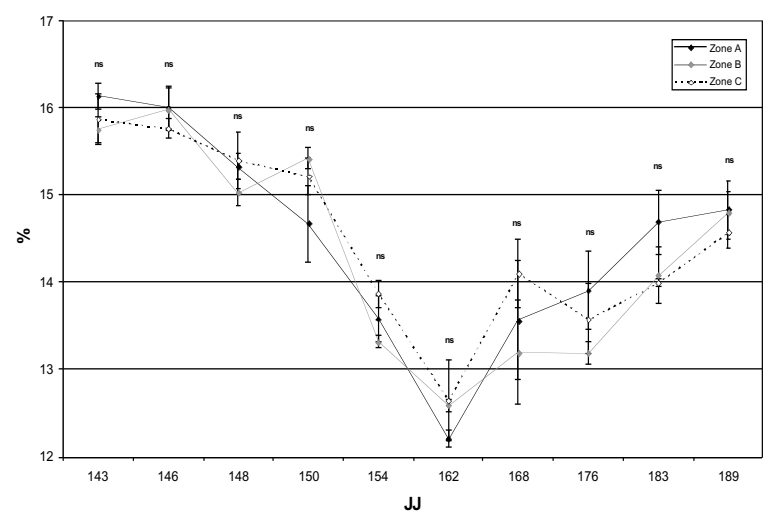

Figure 6. Protein concentration (\%) on dry weight of Tricum aestivum (cv. Centauro). Solid symbols represent the data collected in the zone A, grey symbols data from the zone B and dotted symbols data from zone C. Statistical significant differences are shown on the graph.

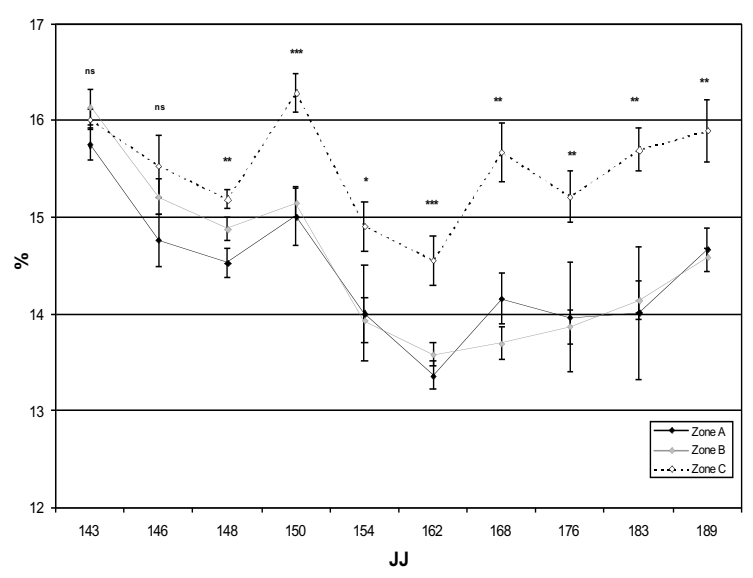

Figure 7. Protein concentration (\%) on dry weight of Tricum durum (cv. IRIDE). Solid symbols represent the data collected in the zone A, grey symbols data from the zone B and dotted symbols data from zone C. Statistical significant differences are shown on the graph.

value was initially around $16 \%$, than dropped to less then $13 \%$ on $11^{\text {th }}$ June and reached a final value of $14.6 \%$ at the time of harvest. In the durum wheat, the heat treatment had, instead, a marked effect on protein concentration (Fig. 7). A clear separation was detectable between the protein concentration of the grains exposed to higher temperature (zone A, B) and that of the grains grown in zone C. Such difference was highly significant at ANOVA on eight out of ten sampling dates. The protein concentration ranged from $16 \%$ on 21 May, to $14.7 \%$ on 11 June and $15.9 \%$ at harvest in zone C, while the corresponding values for zones $\mathrm{A}$ and $\mathrm{B}$, were respectively $16 \%, 13.5 \%$ and $14.6 \%$.

\section{Discussion and conclusion}

The use of infrared radiation to increase the temperature of the plants organs, is straightforward experimental technique, which is easily applicable under field conditions to mimic the effect of increased temperature on growth and plant physiology. However, infrared heating is an artefact, as it basically creates an unbalance between the temperature difference between the surface and the air. Plant energy balance is determined, in the real world, by the net radiation and an equilibrium is maintained in surface-to-air temperature difference (Anderson et al., 2000) while infrared heating unavoidably enhances, in a non realistic way, such a difference. 
In our specific case, the artefact of infrared heating was considered to have a minor effect, as during most of the grain filling period, the wheat leaves are already senesced and therefore an increase in surface temperature decoupled to the temperature of the surrounding air have smaller effect on leaf physiology.

Grain yield and protein concentration in both durum and bread wheat are determined by the plant efficiencies in dry matter partitioning, i.e. the relative rates of carbon and nitrogen translocation and relocation. Protein concentration, in particular, depends on both the capacity of the plant to accumulate carbon and nitrogen in the grains. When carbon accumulation occurs at a high rate, as it happens during the initial phase of grain growth, nitrogen content diminishes, while it tends to increases when carbon accumulation slows down (Fig. 6 and 7). This also explains the common observation that conditions that shorten grain filling duration, affect the final protein concentrations of grains (Jamieson et al., 2004). For the varieties considered, carbon accumulation rate was higher for durum than for bread wheat, but since the protein concentration was, overall, greater in durum than in bread wheat, we can assume that the absolute nitrogen accumulation rates were higher for the former species. Such difference may be either caused by a faster nitrogen uptake rate and translocation or a more efficient relocation of nitrogen accumulated in reserve organs (Kramer, 1979; Jenner et al., 1991; Triboi and Triboi-Blondel, 2002). Temperature had a differential effect between the two species only on nitrogen accumulation rates. Slower nitrogen accumulation was observed in durum wheat under elevated temperature throughout the all grain filling period. Since most of the nitrogen found in the grains at maturity is contained in the storage organs before anthesis (Austin et al., 1977), such observation suggests that nitrogen relocation capacity is limited by temperature. Accordingly, the data of this experiment supports the conclusion that, in absence of major thermal or temperature-induced water stress, an increase in the temperature of the organs causes a decrease in protein concentration of the grains. This is partially in contrast with the hypothesis that, in temperate cereals, leaves are the main source of amino acids for grain protein synthesis, and the degradation of enzymes and pigments is enhanced by high temperatures
(Jenner et al., 1991; Garcia del Moral et al., 1995; Fernandez-Figares et al., 2000). Our data do not elucidate the physiological causes of such an effect as well as the differential effects of temperature on the gliadine and glutenin ratio of accumulated protein that are found in the grains (Triboi and Triboi-Blondel, 2002).

We can assume that heat treatment induced physiological thermo tolerance, without interfering with growth. Alterations of nitrogen translocation patterns to the grains were only observed in durum wheat likely due to an impairement of physiological processes via denaturation of enzymes and/or alteration of cells membrane fluidity (Maheswari et al., 1999).

\section{Acknowledgements}

Alessandro Zaldei, Francesco Sabatini, Cristina Mirenda, Toufic El-Asmar and Giacomo Tagliaferri (IBIMETCNR) are acknowledged for their valuable technical assistance during the experiment, Cesare Ronchi (CO.RI.AL. spa) for the nitrogen analysis on biomass and Bruna Zendrini for the statistical analysis.

\section{References}

Anderson M.C., Norman J.M., Meyers T.P., Diak G.R. 2000. An analytical model for estimating canopy evapotranspiration and carbon assimilation fluxes based on canopy light-use efficiency. Agric. For. Meteorol., 101:265-289.

Anderson W.K., Crosbie G.B., Lemsom K. 1995. Production practices for high protein, hard wheat in Western Australia. Aust. J. Exp. Agric., 35:589-595.

Angus J.F., Fischer R.A. 1991. Grain and protein responses to nitrogen applied to wheat growing on a red earth. Aust. J. Agric. Res., 42:735-746.

Austin R.B., Ford M.A., Edrich J.A., Blackwell R.D. 1977. The nitrogen economy of winter wheat. J. Agric. Sci. Cam., 88:159-167.

Barber J.S. 1987. Factors influencing the grain yield and quality in irrigated wheat. J. Agric. Sci., 109:19-26.

Barbottin A., Lecomte C., Bouchard C., Jeuffroy M.H. 2005. Nitrogen remobilization during grain filling in wheat: genotypic and environmental effects. Crop. Sci., 45:811-1202.

Bhatia C.R. 1975. Criteria for early generation selection in wheat breeding programmes for improving protein productivity. Euphytica, 24 :789-794.

Blumenthal C., Barlow E.W.R., Wrigley C.W. 1993. Growth environment and wheat quality: the effect of heat stress on dough properties and gluten proteins. J. Cereals Sci., 18:3-21. 
Campbell C.A., Davidson H.R., Winkelman G.E. 1981. Effect of nitrogen, temperature, growth stage and duration of moisture stress on yield components and protein content of Manitou spring wheat. Can. J. Plant. Sci., 61:549-563.

Corbellini M., Canevar M.G., Mazza L., Ciaffi M., Lafiandra D., Borghi B. 1997. Effect of the duration and intensity of heat shock during grain filling on dry matter and protein accumulation, technological quality and protein composition in bread and durum wheat. Aust. J. Plant Physiol., 24:245-260.

Dupont F.M., Hurkman W.J., Vensel W.H., Chan R., Lopez R., Tanaka C.K., Altenbach S.B. 2006. Differential accumulation of sulfur-rich and sulfur-poor wheat flour proteins is affected by temperature and mineral nutrition during grain development. J. Cereal Sci., 44:101-112.

Ehdaie H., Waines J.G. 2001. Sowing date and nitrogen rate effects on dry matter and nitrogen partitioning in bread and durum wheat. Field Crop Res., 73,1:47-61.

Fernandez-Figares I., Marinetto J., Royo C., Ramos J.M., Garcia del Moral L.F. 2000. Amino-acid composition and protein and carbohydrate accumulation in the grain of triticale grown under terminal water stress simulated by a senescence agent. J. Cereal Sci., $32: 249-258$

Ferraresi A. 2000. Schede varietali grano tenero, grano duro e orzo. Notiziario Tecnico CRPV, n. 60.

Fischer R.A., Howe G.N., Ibrahim Z.M. 1993. Irrigated spring wheat and timing and amount of nitrogen fertilization. I. Grain yield and protein content. Field Crop Res., 33:37-56.

Flagella Z. 2006. Qualità nutrizionale e tecnologica del frumento duro. Ital. J. Agron./Riv. Agron., 1:203-239.

Garcia del Moral L.F., Boujenna A., Yànez J.A., Ramos J.M. 1995. Forage production, grain yield and protein content in dual purpose triticale grown for both grain and forage. Agron. J., 87:902-908.

Gunthardt H., McGinnis J. 1957. Effect of nitrogen fertilization on amino acids in whole wheat. J. Nutr., 6:167-176.

Jamieson P.D., Zyskowski R.F., Semenov M.A. 2004. Modelling genetic variability in wheat quality. In: VIII European Society for Agronomy Book of Proceedings, 275-276.

Jenner C.F., Ugalde T.D., Aspinall D. 1991. The physiology of starch and protein deposition in the endosperm of wheat. Aust. J. Plant. Physiol., 18:211-26.

Johnson V.A., Mattern P.J., Peterson C.J., Kuhr S.L. 1985. Improvement of wheat protein by traditional breeding and genetic techinques. Cereal Chem., 62:350-355.

Kramer Th. 1979. Environmental and genetic variation for protein content in winter wheat (Triticum aestivum L.). Euphytica, 28:209-218.

Maheswari M., Joshi D.K., Saha R., Nagarajan S., Gambhir P.N. 1999. Transverse relaxation time of leaf water protons and membrane injury in wheat (Triticum aestivum L.) in response to high temperature. Ann. Bot., 84:741-745.

Palta J.A., Fillery I.R.P. 1995. N application enhances remobilization and reduces losses og pre-anthesis $\mathrm{N}$ in wheat grown on a deplex soil. Aust. J. Agric. Res., 46:519-531.

Rao A.C.S., Smith J.L., Jandhyala V.K., Papendick R.I., Parr J.F. 1993. Cultivar and climatic effects on protein content of soft white winter wheat. Agron. J., 85:1023-1028.

Rharrabti Y., Villegas D., Garcia del Moral L.F., Aparicio N., Elhani S., Royo C. 2001. Environmental and genetic determination of protein content and grain yield in durum wheat under Mediterranean conditions. Plant Breed., 120:381-388.

Rharrabti Y., Royo C., Villegas D., Aparicio N., Garcia del Moral L.F. 2003 (a). Durum wheat quality in Mediterranean environments I. Quality expression under different zones, latitudes and water regimes across Spain. Field Crop Res., 80:123-131.

Rharrabti Y., Villegas D., Royo C., Martos-Numez V., Garcia del Moral L.F. 2003 (b). Durum wheat quality in Mediterranean environments II. Influence of climatic variables and relationships between quality parameters. Field Crop Res., 80:133-140.

Rostami M.A., O'Brien L. 1996. Differences among bread wheat genotypes for tissue nitrogen content and their relationship to grain yield and protein content. Aust. J. Agric. Res., 47:33-45.

Spiertz J.H., van de Haar H. 1978. Differences in grain growth crop photosynthesis and distribution of assimilates between a semidwarf and a standard cultivar of winter wheat. Neth. J. Agric. Sci., 26:233- 249.

Spiertz J.H., Hamer R.J., Xu H., Primo-Martin C., Don C., van der Putten P.E.L. 2006. Heat stress in wheat (Triticum aestivum L.): effects on grain growth and quality traits. E.J. Agron., 25:89-25.

Sosulski F.W., Imafidon G.I. 1990. Amino acid composition and nitrogen-to-protein conversion factors for animal and plant foods. J. Agric. Food Chem., 38:13511356.

Triboi E., Triboi-Blondel A.M. 2002. Productivity and grain or seed composition: a new approach to an old problem. Eur. J. Agron., 16:419-423.

Troccoli A., Borrelli G.M., De Vita P., Fares C., Di Fonzo N. 2000. Durum wheat quality: a multidisciplinary concept. J. Cereal Science, 32:99-113.

Uhlen K.A., Hafskjold R., Kalhovd H., Sahlstrom S., Longva A., Magnus E.M. 1998. Effects of cultivars and temperature during grain filling on wheat protein content, composition, and dough mixing properties. Cereal Chem., 75:460-465.

Usda 2005. Production Estimates and Crop Assessment Division Foreign Agricultural Service (http:// 151.121.3. 140/pecad/highlights/2005/07/durum2005/index.htm) 
van Herwaarden A.F., Angus J.F., Richards R.A., Farquhar G.D. 1998. "Hayin-off" the negative grain yield response of dryland wheat to nitrogen fertiliser. II Carbohydrate and protein dynamics. Aust. J. Agric. Res., 49:1083-1093.

Wrigley C.W., Batey I.L., Uthayakumaran S., Rathmell
W.G. 2006. Modern approaches to food diagnostics for grain quality assurance. Food Australia, 58,11: 538-542.

Zadoks J.C., Chang T.T., Konzak C.F. 1974. A decimal code for the growth stages of cereals. Weed Res., 14:415-421. 